\title{
CONSIDERATIONS ON THE ELEMENTS OF MUSICAL LANGUAGE IN LA CASA DI PESTE DRUM \\ [AT THE HOUSE ACROSS THE ROAD] BY TUDOR JARDA
}

\author{
Associate Professor, Ph.D. ILDIKÓ KALLÓ \\ National Music Academy "Gheorghe Dima" of Cluj-Napoca
}

Ildikó KALLÓ, associate professor at Piatra Neamț, branch of the National Music Academy of "Gheorghe Dima" ClujNapoca, with a Ph.D. in music since 2006. Numerous concerts with the Piatra Neamț Branch choir and orchestra from 1998 to 2014. Colaborated with the "Mihail Jora" Philharmonic of Bacău; The National Opera House of Iași; The "Moldova" Philharmonic of Iași; the Philharmonic of Szekler (Odorheiu-Secuiesc). In 2014 she establishes the choral group Extensio with in the Piatra Neamț Branch, with which she holds numerous choral and vocal-instrumental concerts. Author of two books: Estetica artei interpretative corale din Transilvania [Aesthetics of choral performances art in Transylvania] and Dirijori ardeleni - Lucian Surlaşiu, Nagy

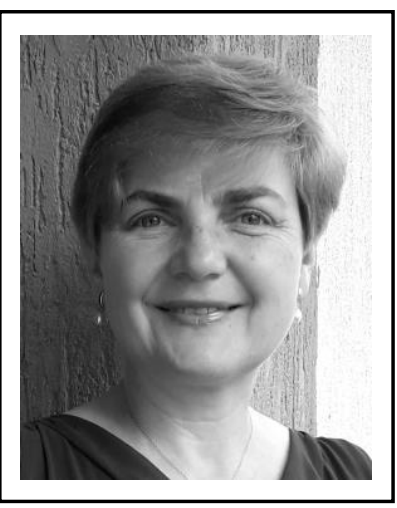
István, Dorin Pop [Transylvanian choral conductors - Lucian Surlaşiu, Nagy István, Dorin Pop], publisher: MediaMusica in 2008, Cluj-Napoca.

\section{ABSTRACT}

La casa di peste drum [At the House across the Road] is, perhaps, Tudor Jarda's most emblematic choral work, being the first composition of the 10 carols for mixed choir included in the volume Coruri [Choral Works] (1981). Dedicated to Maestro Dorin Pop and the Cappella Transylvanica choir, this work has been part of the ensemble's repertoire since the publication of the collection, being also found in the repertoire of the most important Cluj and Transylvanian choirs. This paper aims to detail aspects of musical grammar in the choral work La casa di peste drum, highlighting the close connection between the text and music and its implications in the choral interpretation. The morphological and syntactic analysis also highlights certain characteristics of Tudor Jarda's choral writing.

Keywords: Cappella Transylvanica, carols, choral work, modal, polyphonic

The choral work La casa di peste drum [At the House across the Road] ${ }^{1}$ is a secular carol ${ }^{1}$ collected by Tudor Jarda himself from the Bistrița region, arranged and harmonized in the most elevated polyphonic and modal harmonic style.

\footnotetext{
${ }^{1}$ Tudor Jarda, Coruri [Choral Works], Editura Muzicală, Bucharest, 1981.
} 
From a thematic point of view, the carol La casa di peste drum is one of the carols addressed to the householder, i.e. to the owner of the house where the carol is sung. The text preserves the Transylvanian dialect, including words such as târnaț [porch], vadră [bucket], colac [bread], specific to this Romanian region and where the householder is called gazdă [host]. The carol has seven stanzas, of which the first five have a refrain, while the following two have no refrain. In Maestro Jarda's choral version, the sixth stanza is optional and is omitted in most interpretations. Here is the text of the carol:

\begin{tabular}{|c|c|}
\hline $\begin{array}{l}\text { 1. La casa di peste drum, florile- } n \text { dalbe, } \\
\text { [At the house across the road, } \underline{\text { white flowers }} \text { ] } \\
\text { Boii-s cu coarnile-ntoarse } \\
\text { [The oxen have twisted horns]; }\end{array}$ & $\begin{array}{l}\text { 4. Scoală gazdă, dă-mi plăcintă, florile- } n \text { dalbe } \\
\text { [Wake up host, give me some pie, } \\
\text { white flowers], } \\
\text { Ca s-auzi colinda-n tindă } \\
\text { [If you want to hear the carol on your porch]. }\end{array}$ \\
\hline $\begin{array}{l}\text { 2. Scoală gazdă, dă-mi colacu, florile- } n \text { dalbe } \\
\text { [Wake up host, give me some bread, white flowers } \\
\text { Ca s-auzi colinda-n prag. } \\
\text { [If you want to hear the carol in your doorway]. }\end{array}$ & $\begin{array}{l}\text { 5. Că de-asară stăm pe-afară, florile-n dalbe } \\
\text { [For since last night we've been outside, } \\
\text { white flowers], } \\
\text { Că de-asară stăm pe-afară. } \\
\text { [For since last night we've been outside] }\end{array}$ \\
\hline $\begin{array}{l}\text { 3. Scoală gazdă, dă-mi cârnaț, florile- } n \text { dalbe } \\
\text { [Wake up host, give me a sausage, white flowers], } \\
\text { Ca s-auzi colinda-n prag } \\
\text { [If you want to hear the carol in your doorway]. }\end{array}$ & $\begin{array}{l}\text { (6. Scoală gazdă, dă-mi plăcintă } \\
\text { [Wake up host, give me some pie], } \\
\text { Scoală gazdă, dă-mi slănină } \\
\text { [Wake up host, give me some bacon], } \\
\text { Scoală gazdă, dă-mi colacu' } \\
\text { [Wake up host, give me some bread]) }\end{array}$ \\
\hline $\begin{array}{l}\text { 7. Scoală gazdă, dă-mi plăcintă } \\
\text { [Wake up host, give me some pie] } \\
\text { Ca s-auzi colinda-n tindă } \\
\text { [If you want to hear the carol on your porch] } \\
\text { Că de-asară stăm pe-afară } \\
\text { [For since last night we've been outside] }\end{array}$ & $\begin{array}{l}\text { Recitative: } \\
\text { Să fiți gazdă sănătoas', să plătiți colinda noast' } \\
\text { [We wish you, host, good health, and to pay } \\
\text { for our carolling] } \\
\text { C-un colac frumos de grâu și c-o vadră de vin bun } \\
\text { [With a nice wheat bread and a bucket of } \\
\text { good wine] } \\
\text { C-așa-i datu' la Crăciun } \\
\text { [For this is the custom at Christmas time] } \\
\text { Să cântăm, să colindăm și gazdelor să-nchinăm } \\
\text { tot în dalba sănătate } \\
\text { [To sing, go carolling and cheer for our } \\
\text { [Hasts'good health] } \\
\text { La mulți ani! Happy New Year!] } \\
\text { Vină gazdă la corindă } \\
\text { [Come out, host, to our carolling]. }\end{array}$ \\
\hline
\end{tabular}

1 The carol is the musical production of the most celebrated custom in the literary and musical works of the winter cycle repertoire. Carolling is a highly popular custom, widely spread all over the country, an occasion on which people share wishes for wealth and happiness in the new year. Carols can be grouped into two main categories: religious carols, with texts on the story of the Nativity, and secular carols, whose themes are very diverse. The theme of the secular carols varies depending on the audience they are addressed to: the householder, the housewife, the girl, the lad, the shepherd, the hunter, the fisherman, etc. Traian Mârza, Ileana Szenik, Curs de folclor muzical [Musical Folklore Course], vol. I, part II, Cluj-Napoca Conservatory of Music. 
Morphologically, the sound material of the choral work consists of an Aeolian pentachord:

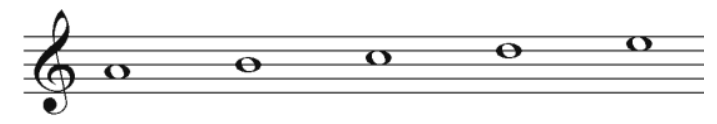

The carol has two main motifs - each corresponding to a verse - and a refrain, interspersed between the two verses, thus totalling three motifs that bind the work together.

The first motif has an arched melodic line, built on the trichord $A-B-C^{2}$ and starting with a leap of a minor third, followed by a gradual downward motion. The rhythm is giusto syllabic, which is the rhythmic system specific to the Romanian carol. The division of the original carol into measures generates a heterogeneous meter, with the two $2 / 4$ measures inserted in a 3/8 measure, lending the musical discourse a subtle symmetry, despite the binary-ternary alternation.

The refrain is based on a motif with a sinuous melodic profile, ascending-descending-ascending, on the tetrachord $C^{2}-F^{2}$. The syllabic, syncopated rhythm is followed by two groups of two melismatic eighth-notes. The meter is binary in both measures.

The second motif has a descending line, its sounds forming a pentachord with an Aeolian cadence on the first degree. One can notice the rhythmic symmetry with that of the first verse.

The rhythmic construction is based on a heterogeneous configuration of the motifs carrying the lyrics, where each motif is three measures long $(2 / 4+3 / 8+$ $3 / 4)$, compared to the homogeneous configuration $(2 / 4+2 / 4)$ of the refrain, which consists of only two measures. The symmetry of the two verses interspersed by the refrain gives balance to the musical stanza. The meter is not constant, it follows the prosody of the text, so that the $2 / 4,3 / 8,3 / 4$ measures are alternated throughout the entire piece. The rhythm is giusto syllabic, with the few melismas being placed in the refrain and playing an ornamental role.

The compositional elaboration is characterized by a different treatment of each stanza. (This compositional method is specific to Tudor Jarda's multi-strophic choral works).

The tempo is Allegretto, while the tempo of the final recitative is Vivo, recitativo. The piece features a wide dynamic range, from the finest shades of $p p p$ to $f f$.

The first two stanzas are composed homophonically, differing only in harmonization, and have the same number of measures, i.e. 8 measures each, divided into $3+2+3$. Both cadences are Aeolian, with no thirds.

The accompaniment of the first two stanzas is based on the sound material of the Aeolian pentachord on which the carol rests, while the dissonances of a second do not have the role of tensing the musical material, but result from the 
linear treatment of the inner voices and do not require a resolution. The alteration of the note $\mathrm{F}$ in measure 7 is due to the inversion of motif 2 in the bass part, in contrary motion to the soprano.

The text of the second stanza calls for a forte nuance, as notated by the composer in the score. We notice the expressive effect of the leap of a minor seventh in the bass part, on the word dă-mi [give me], reflecting precisely the urgent desire of the carollers to receive the bread from the host.
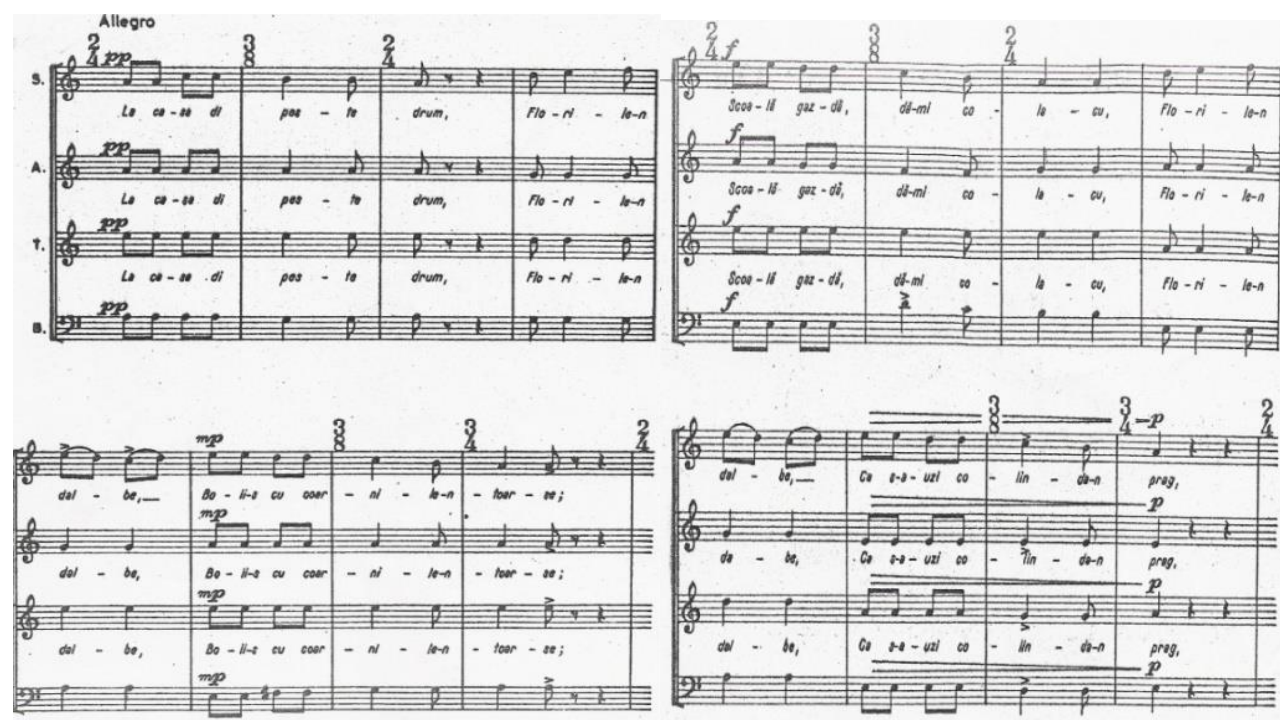

Example 1: Tudor Jarda, La casa di peste drum [At the House across the Road], the $1^{\text {st }}$ and $2^{\text {nd }}$ stanzas

The third stanza is harmonized polyphonically. The soprano leads the main melody, the tenor holds a long $E^{1}$ (ison) and the bass accompanies these two voices with the melody of motif 2 . In turn, the alto and tenor enter with the melody of the same motif 2, but starting from different scale degrees. The first entrance of the bass and the entrance of the alto is on the fifth scale degree, while that of the tenor and the second entrance of the bass will be on the first scale degree. Due to the polyphony, this stanza is extended to twelve measures, of which the first nine are polyphonic and the last three homophonic. The cadence falls on the second $A-G$, with $G$ being the seventh degree of the Aeolian, which emphasizes the modal character. 


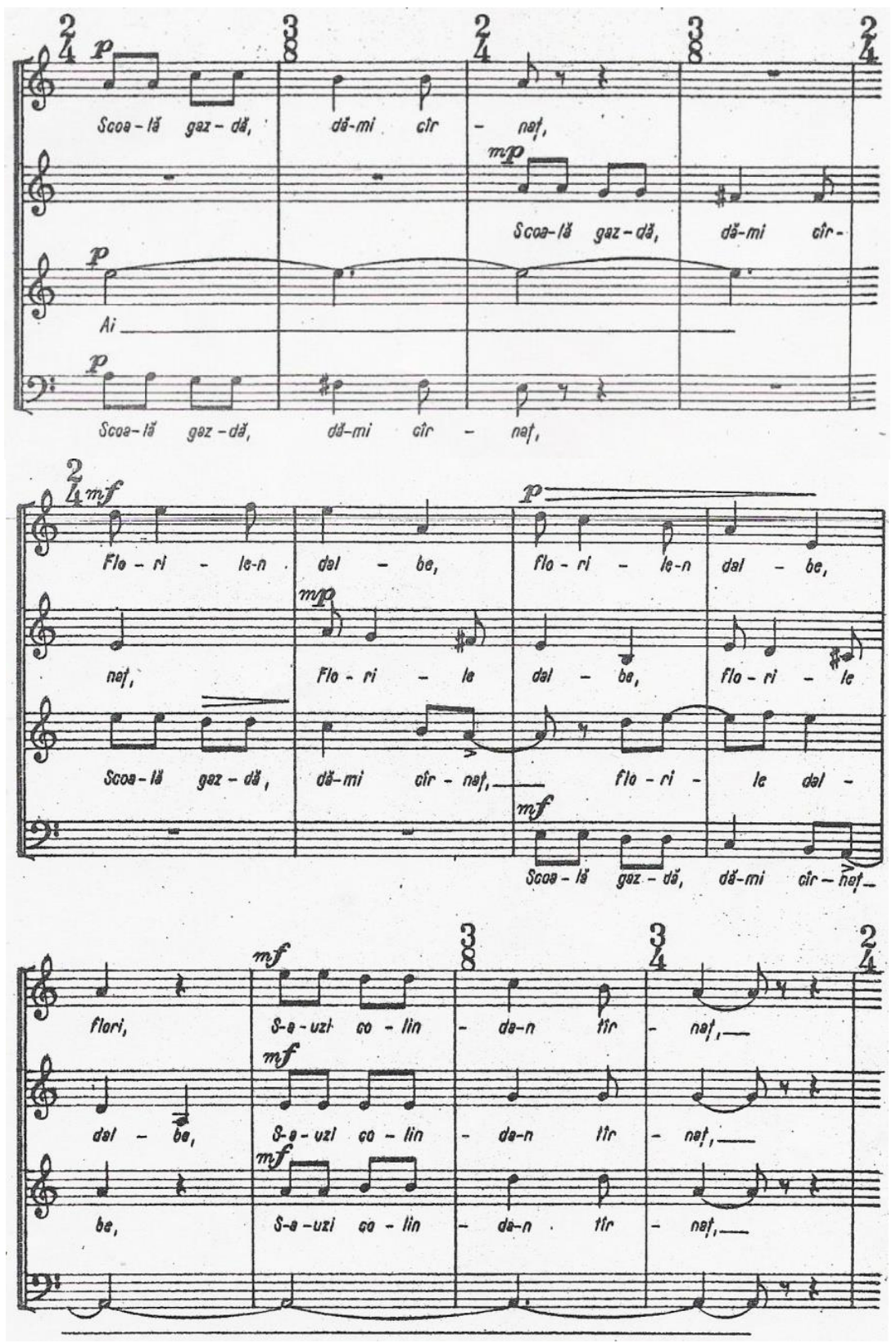

Example 2: Tudor Jarda, La casa di peste drum [At the House across the Road], the $3^{\text {rd }}$ stanza

The fourth stanza makes use of the polyrhythm as an element of musical language, a technique used in almost all the carols in this collection. A homophonic polyphony is created between the male and female voices, as well as a mixture of $E$ and $A$ Aeolian, with the pairs of voices evolving in parallel-fourth motion. 
The note $B$ flat introduced in the tenor part brings a slight modal influence in the acoustic mode 1 . Both the first verse and the refrain are treated based on this technique, while the second verse shifts back to homophony. The homophonic moment is produced by moving in parallel-fifth motion, with each voice being treated linearly, resulting in dissonances that finally converge into a chord of fourths on $E$, restoring the consonance.
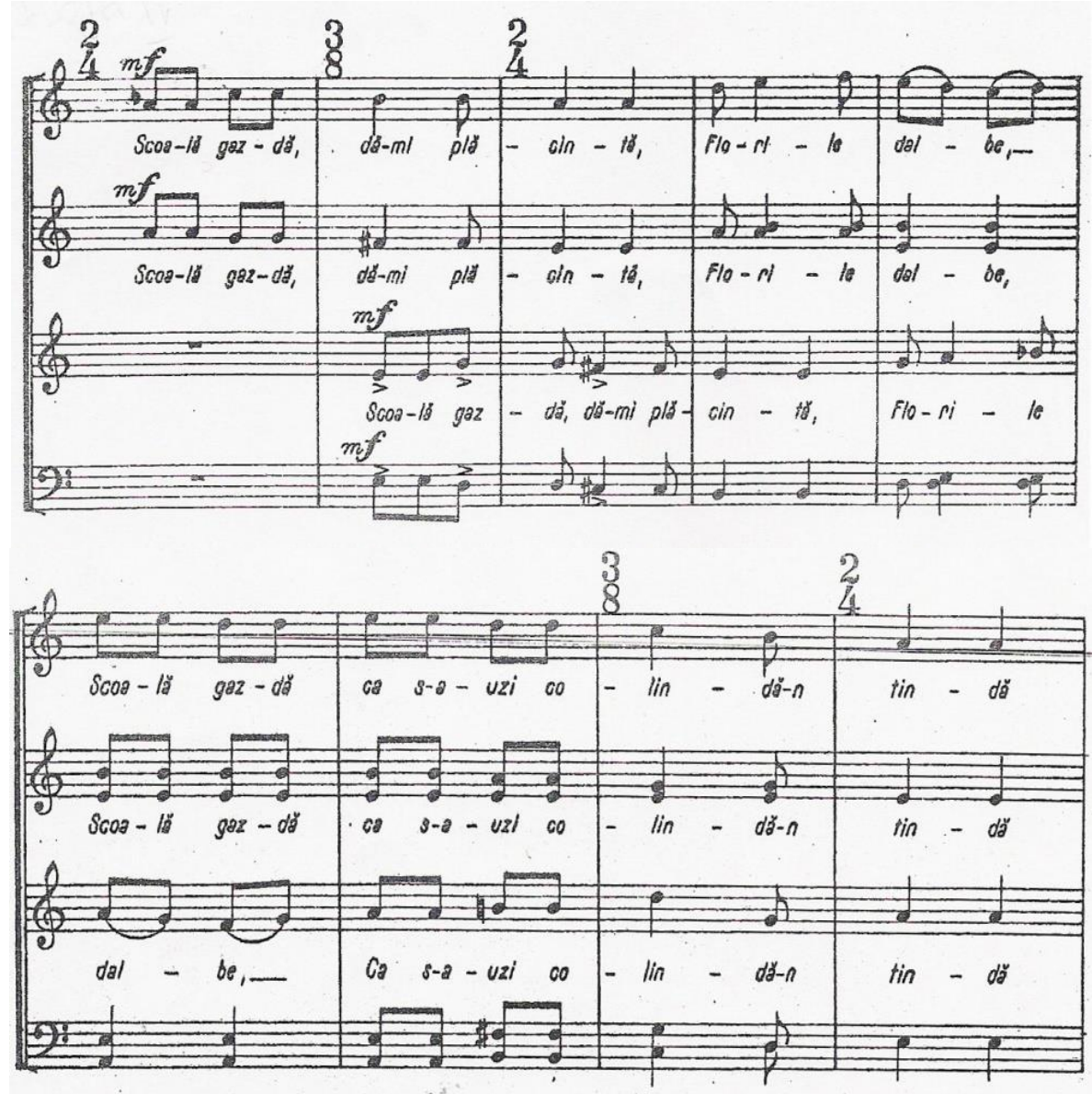

Example 3: Tudor Jarda, La casa di peste drum [At the House across the Road], the $4^{\text {th }}$ stanza

The fifth stanza is homophonic, with certain rhythmic asymmetries emphasizing the aleatoric nature of the execution of this genre. These small rhythmic "disturbances" occur in the third and last measure of the stanza. In terms of harmony, we notice the use of parallelisms of fourths and fifths between voices, along with the pairs of voices moving in contrary motion. 


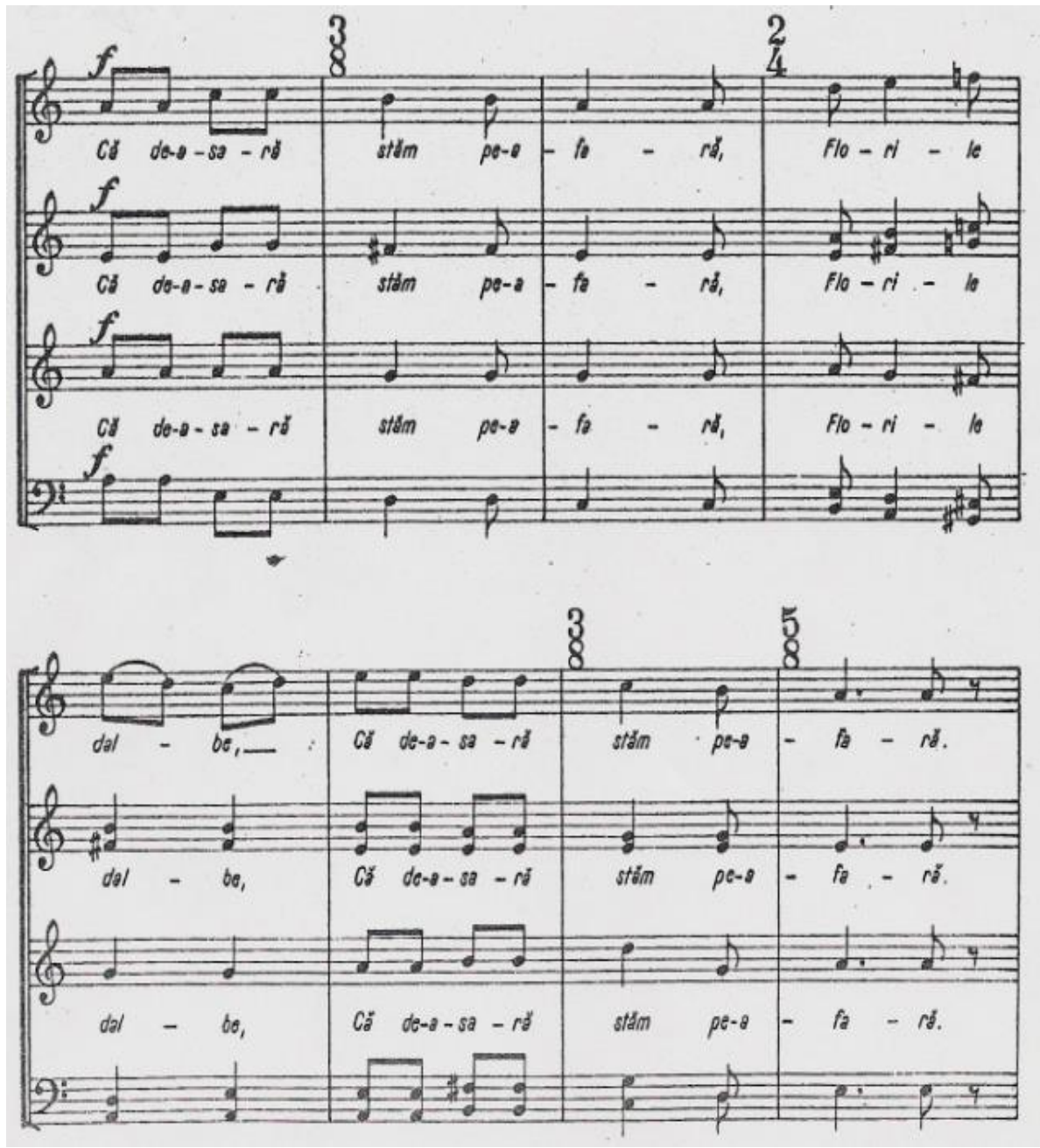

Example 4: Tudor Jarda, La casa di peste drum [At the House across the Road], the $5^{\text {th }}$ stanza

Beginning with the sixth stanza, which can be omitted, the refrain disappears and the melody acquires a different configuration. Three verses at a time are repeated on the same melody, with the sixth stanza using the musical material of motif 2 and the seventh stanza using motif 1, and with the two stanzas reaching a homophonic, conclusive climax after exhausting all the repetitions of the two stanzas. The sixth stanza is the most tense stanza of the piece. The juxtaposition of the parallel fifths on different tetrachordal scales results in mixtures of Major-minor, false relations, true clusters, while the musical discourse becomes more serene in the following stanza, with the return of the Aeolian mode. A climax is reached at the end of the seventh stanza, achieved both through a 
vigorous forte and by extending the durations and changing the rhythmic structure, while the final cadence is placed on an extended fermata.
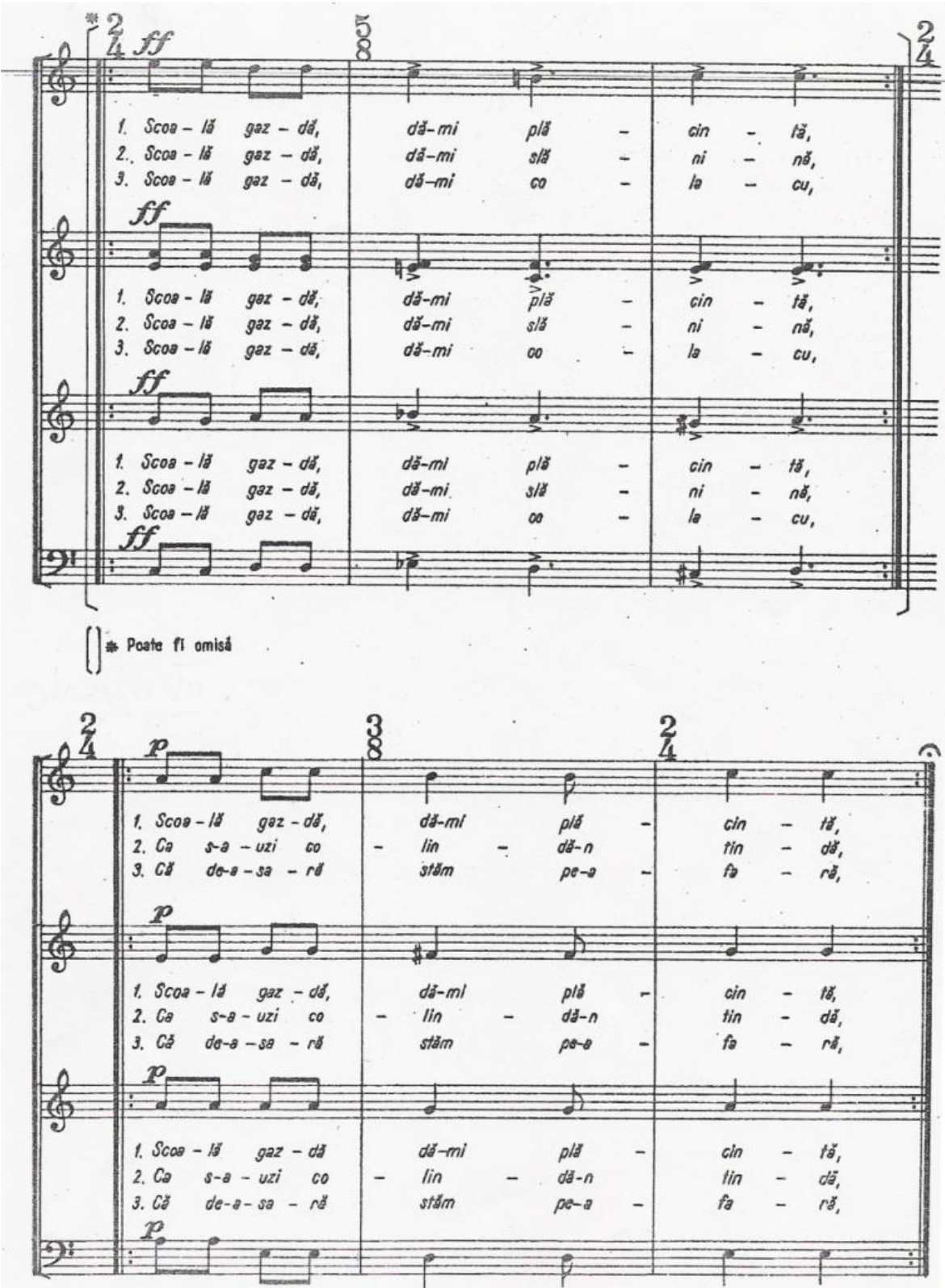


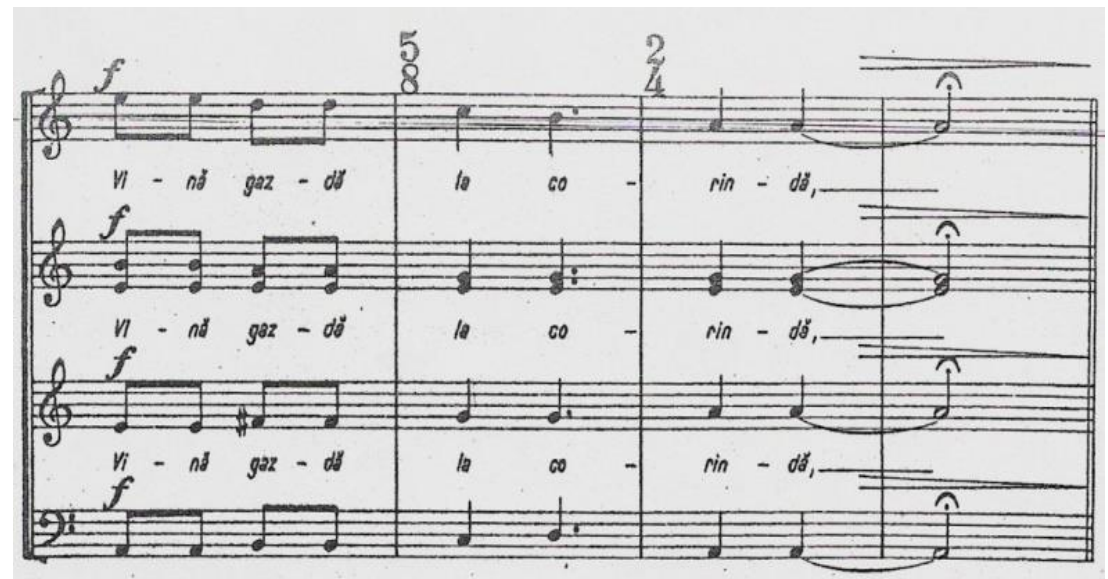

Example 5: Tudor Jarda, La casa di peste drum [At the House across the Road], the $6^{\text {th }}$ and $7^{\text {th }}$ stanzas

The recitative begins with a dialogue between the female voices, which gradually develops, by adding the male voices, into a final cluster, completing the voices of the ensemble on the final wish La Mulți Ani! [Happy New Year!]. The sound material used in the recitative part can be synthesized in two hexatonal and one pentatonal scale:

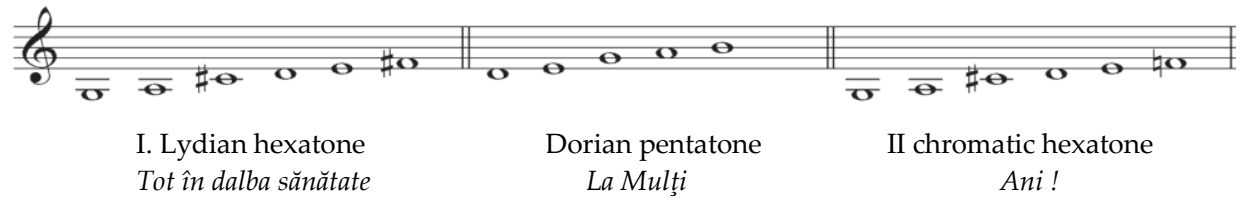

Of special interest in this recitative is the dynamics. Although with the gradual addition of voices the overall nuance should increase, Jarda grades the nuances in opposite direction, with the final cluster being required in ppp. The cluster is meant to suggest the shivering of the carollers, freezing in front of the host's house, and the increasingly smaller nuances allude to a gradual distancing, creating a very plastic image of the carollers leaving the host's house to go to another house, hoping that their carolling will be welcome, while the dissonances used in the musical discourse amplify this atmosphere of slight disorganization of the carollers. The recitative, although notated, must follow closely the prosody of the text, therefore the interpretation will not take into account the notation, but rather the meaning and prosodic accents of the text.

The last three measures of the recitative are the ones that are the least faithful to the notation in the score, gradually fading into the $p p p$ nuance and a rallentando. 
The end of the piece brings back Tempo I by resuming motif 1 , with the text Vină gazdă la corindă [Come out, host, to our carolling], ending the piece in a diatonic style. In terms of image, this final return of the opening motif may illustrate the carolling custom. We can imagine that the last verse is sung already at the house of the next host, the carol being repeated cyclically at each house in the village.

From a conducting and interpretive standpoint, the range of the piece is narrow, due to the narrow range of the carol (pentachord), $A^{1}-E^{2}$, with the last note $F^{2}$ being a passage note. Due to the linear harmonization, without spectacular leaps or modulations and keeping the basic mode, the range of the choral voices does not require significant distances either.

A work of rare beauty, composed with great skill, but also with love for the genre of the carol, La casa di peste drum can be included as a highlight of the repertoire of any professional or highly trained amateur choir. It can stand at the beginning of a concert, as an opening piece, but it can just as well be interspersed between other works of the Romanian or world music.

Despite its comfortable, narrow range, this work is generally not recommended to amateur choirs, due to the multiple metro-rhythmic, melodic and interpretive difficulties it poses. Amateur choirs may encounter the following difficulties in the execution of the piece: rhythmic and metrical delays between the stanzas arising from the non-compliance with the individuality of each stanza, or a poor intonation due to the marked presence of dissonances of a second throughout the piece.

The interpretation of the piece requires lightness in execution on the part of the choir, in order to accurately render the various states and to create a wide range of dynamic levels. Regarding the tempo of the piece, worthy of mention is the agogic stability, the increase in tension until the moment of the recitative, and the negative gradation of the nuances of the recitative, thus increasing continually the tensional state. In the score, the finale is in Tempo I, but the appearance of the main theme at the end gives the conductor freedom to opt for different variants of interpretation.

The piece was dedicated to Maestro Dorin Pop and the Cappella Transylvanica choir, being the first in the cycle of 10 carols published by the composer. Since its very first performance, the piece has been preserved in the choir's repertoire, being one of its most often-performed works. I do not think we exaggerate if we say that most of the choirs from Cluj have this piece in their repertoire, along with other choral masterpieces of Maestro Tudor Jarda. It is also included in the repertoires of the choral competitions of the music high schools, and for decades it has been part of the repertoire of the Conducting course at the National Academy of Music "Gheorghe Dima” in Cluj-Napoca. 


\section{BIBLIOGRAPHY}

JARDA, Tudor, Coruri, Editura Muzicală, Bucharest, 1981

KALLÓ, Ildikó, Arta interpretativă corală din Transilvania. Etape, stiluri, personalități, doctoral thesis, A.M.G.D., Cluj-Napoca, 2006

MÂRZA, Traian, SZENIK, Ileana, Curs de folclor muzical, vol. I, part II, Gh. Dima Conservatory of Music, Cluj-Napoca, 1969

\section{APPENDIX}

Front cover

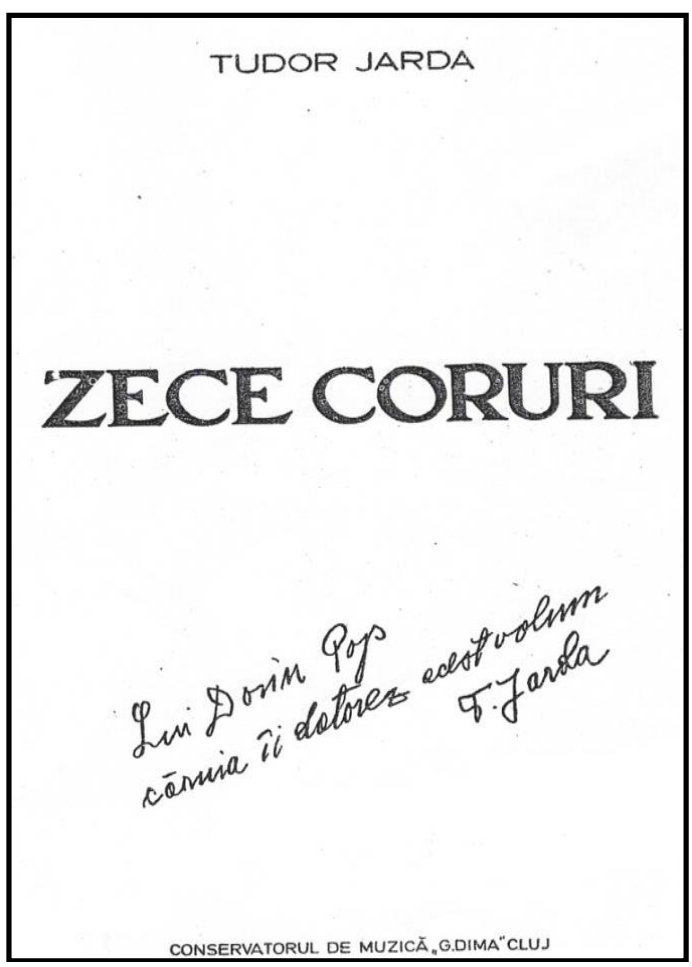

